Article

\title{
Simulation of Silicon Heterojunction Solar Cells for High Efficiency with Lithium Fluoride Electron Carrier Selective Layer
}

\author{
Muhammad Quddamah Khokhar ${ }^{1}$, Shahzada Qamar Hussain ${ }^{2}$, Duy Phong Pham ${ }^{1}$, \\ Sunhwa Lee ${ }^{1}$, Hyeongsik Park ${ }^{1}$, Youngkuk Kim ${ }^{1}$, Eun-Chel Cho ${ }^{1, *}$ and Junsin $\mathrm{Yi}^{1}{ }^{1, *}$ \\ 1 College of Information Communication Engineering, Sungkyunkwan University (SKKU), \\ Suwon 16419, Korea; quddamah@skku.edu (M.Q.K.); pdphong@skku.edu (D.P.P.); \\ ssunholic@skku.edu (S.L.); richspark@skku.edu (H.P.); bri3tain@skku.edu (Y.K.) \\ 2 Department of physics, COMSATS University Islamabad, Lahore Campus, Lahore 54000, Pakistan; \\ sqamar@cuilahore.edu.pk \\ * Correspondence: echo0211@skku.edu (E.-C.C.); junsin@skku.edu (J.Y.); Tel.: +82-010-8595-5412 (E.-C.C.); \\ $+82-010-4257-7139$ (J.Y.)
}

Received: 14 February 2020; Accepted: 24 March 2020; Published: 2 April 2020

\begin{abstract}
In this work, to ameliorate the quantum efficiency (QE), we made a valuable development by using wide band gap material, such as lithium fluoride $\left(\mathrm{LiF}_{\mathrm{x}}\right)$, as an emitter that also helped us to achieve outstanding efficiency with silicon heterojunction (SHJ) solar cells. Lithium fluoride holds a capacity to achieve significant power conversion efficiency because of its dramatic improvement in electron extraction and injection, which was investigated using the AFORS-HET simulation. We used AFORS-HET to assess the restriction of numerous parameters which also provided an appropriate way to determine the role of diverse parameters in silicon solar cells. We manifested and preferred lithium fluoride as an interfacial layer to diminish the series resistance as well as shunt leakage and it was also beneficial for the optical properties of a cell. Due to the wide band gap and better surface passivation, the $\mathrm{LiF}_{\mathrm{x}}$ encouraged us to utilize it as the interfacial as well as the emitter layer. In addition, we used the built-in electric and band offset to explore the consequence of work function in the $\mathrm{LiF}_{\mathrm{x}}$ as a carrier selective contact layer. We were able to achieve a maximum power conversion efficiency (PEC) of $23.74 \%$, fill factor (FF) of $82.12 \%$, $\mathrm{J}_{\mathrm{sc}}$ of $38.73 \mathrm{~mA} \mathrm{~cm}^{-2}$, and $\mathrm{V}_{\mathrm{oc}}$ of $741 \mathrm{mV}$ by optimizing the work function and thickness of $\mathrm{LiF}_{\mathrm{x}}$ layer.
\end{abstract}

Keywords: lithium fluoride; electron selectivity contact layer; electric field; work function; silicon heterojunction solar cell

\section{Introduction}

Comprehensive consideration is needed when working with silicon heterojunction (SHJ) solar cells due to the fact of their low-temperature fabrication process and capability of gaining higher power conversion efficiency (PEC). The SHJ solar cells at p-type/Si (n- as well as p-layer) and n-type/Si (nplus p-layer) interfaces, with intrinsic thin amorphous silicon layers (i-layer), have invoked substantial interest due to the fact of their excellent thermal budget compared to conventional solar cells as well as having the highest PCE [1-8]. Over the last twenty years, cutting edge research on SHJ solar cells has developed several advantages: (a) a short and cost-efficient production procedure; (b) inferior degradation and ameliorate stability; (c) inferior processing temperature; and (d) high open-circuit voltage $\left(V_{\text {oc }}\right)[5,9]$. Further improvement in the performance of $\mathrm{SHJ}$ solar cells have been made based on various efforts in the following areas: (1) surface passivation by employing superior quality for 
diminishing carrier recombination losses; (2) reduction of carrier collection losses by utilizing thinner wafers; and (3) diminution of parasitic absorption losses.

Normally, in the case of silicon solar cells, good quality silicon wafers are used as a substrate for cell fabrication, but in the case of on-chip antennas, we observed the opposite condition for a silicon substrate. The previous antennas exhibit superior transmission loss and are not designed for radiation patterns. Although, recently they usually have employed supplementary processing steps to raise the silicon substrate's resistivity in an effort to ameliorate the antenna's performance. Still, the primary challenge is insufficient radiation efficiency because of the loss in silicon substrate. An effort has been made to enhance the gain and radiation efficiency of the on-chip antenna by means of an un-doped silicon substrate as well as a large silicon lens towards the backside about a particular chip [10-17]. But, if we talk about solar cells, the main limitations of SHJ solar cells' efficiency are due to the low optical absorption of a-Si:H(i); high doping defects of a-Si:H(p/n); narrow bandgap; and low conductivity of the n-layer on the front side $[18,19]$. Nevertheless, the comparatively low conversion efficiency, primarily resulting from the so-called "Staebler-Wronski effect", continues to be the major technical challenge to superior competitiveness. For the purpose of diminishing the light-induced degradation of the solar cells, thin intrinsic (i-a-Si:H) absorbers are favorable. Nevertheless, thin i-a-Si:H cannot absorb sufficient light because of its indirect band gap nature, therefore restricting the short-circuit current $\left(\mathrm{J}_{\text {sc }}\right)$ of the solar cells. To beat the low absorption issue, light trapping tactics for the cells are of high interest. For that purpose, we investigated the stake of $\mu \mathrm{c}-\mathrm{SiO}_{\mathrm{x}}(\mathrm{n})$ and $\mathrm{LiF}_{\mathrm{x}}$ targeting to improving the optical path length within solar cells. To boost the cell's efficiency further in order to reach the Si limitation, alternative materials with a higher work function, wide bandgap, and high conductivity instead of a-Si:H(p) layer, so-called transition metal oxide (TMOs) films were introduced. Wide bandgaps with high work function-based materials, such as molybdenum oxide $\left(\mathrm{MoO}_{\mathrm{x}}\right)$, vanadium oxide $\left(\mathrm{V}_{2} \mathrm{O}_{\mathrm{x}}\right)$, tungsten oxide $\left(\mathrm{WO}_{\mathrm{x}}\right)$, and nickel oxide $\left(\mathrm{NiO}_{\mathrm{x}}\right)$, have been proposed as hole transport layers (HTLs) for high efficiency SHJ solar cells [20-25]. Similarly, to achieve a high performance for SHJ solar cells, wide bandgaps with low work function-based materials, such as lithium fluoride $\left(\mathrm{LiF}_{\mathrm{x}}\right)$, magnesium fluoride $\left(\mathrm{MgF}_{\mathrm{x}}\right)$, titanium oxide $\left(\mathrm{TiO}_{\mathrm{x}}\right)$, and cesium iodide $(\mathrm{CsI})$, have been proposed as electron transport layers (ETLs) [26-30].

There are several parameters in the AFORS-HIT simulation for an improvement in the performance of solar cells. The three parameters discussed in this manuscript are selective collection of photo-generated charge carriers, surface defect passivation, and available light to the absorber layer, and have been conceived significantly [2,3,31-33]. Hence, various researchers have performed multiple studies on these parameters. In this study, low work function values with transparent materials were preferred to attain carrier selectivity. Ideally, on lightly doped c-Si, when a low work function material is applied, the collection of electrons (as well as repulsion of holes) happens close to the surface. This extreme concentration of electrons on surface diminishes particular heterocontact resistivity, and the chance of Shockley-Read-Hall recombination reduces due to the corresponding low hole surface concentration at the heterocontact interface. This result is opposed for the high work function and holes materials. Our present investigation was operated using low work function, wide band gap, and a thin layer of lithium fluoride $\left(\mathrm{LiF}_{\mathrm{x}}\right)$. The $\mathrm{LiF}_{\mathrm{x}}$ was used as an electron carrier selective contact material with applications for an optimized interfacial layer in silicon heterojunction (SHJ) solar cells. Our intention was to enhance the carrier collection selectivity, build more light accessibility to the absorber layer, and reduce the barrier height at the front interface. A wide band gap can encourage sharp band bending that successively assists carrier selectivity. It has been commonly known that low work function material is preferred for constituting a small barrier height towards electron transport.

Our report consists of a simulated study of carrier selective contact using $\mathrm{LiF}_{\mathrm{x}}$ layers with various thicknesses and a work function for the optimization of SHJ solar cells' performance. First, the performance of the $\mathrm{SHJ}$ solar cells was studied as a function of $\mathrm{LiF}_{\mathrm{x}}$ layer thickness. With an interfacial layer of $\mathrm{LiF}_{\mathrm{x}}$ with $2 \mathrm{~nm}$ thickness, the $\mathrm{SHJ}$ solar cells attained a high efficiency up to $23.74 \%$. Due to the better surface passivation, the $\mathrm{LiF}_{\mathrm{x}}$ layer can accomplish a supreme carrier life-time to assure prominent 
open circuit voltage $\left(\mathrm{V}_{\mathrm{oc}}\right)$ output. The influence of the $\mathrm{LiF}_{\mathrm{x}}$ work function on the performance of $\mathrm{SHJ}$ solar cells is thus presented.

\section{Simulation Model}

Theoretical modeling as well as simulation studies are commonly conducted to ameliorate the efficiency of silicon solar cells. Lately, numerous modeling and simulations have been associated with SHJ and carrier selective contact (CSC) solar cells. The AFORS-HET simulator is widely utilized for the study of SHJ solar cells and to solve one-dimensional Poisson and carrier continuity equations. A recombination model, such as Shockley-Read-Hall (SRH), is employed to simulate a particular semiconductor equation in favor of steady-state conditions.

For the development of an efficient $\mathrm{SHJ}$ cell, it is necessary to optimize the $\mathrm{LiF}_{\mathrm{x}}$ layer. Our simulations results were based on experimental data extracted in the form of (n, k) files for $\mathrm{LiF}_{\mathrm{x}}$ films and plugged into AFORS-HET for the purpose of simulation [27,34,35]. For the generation of experimental data, we deposited lithium fluoride $\left(\mathrm{LiF}_{\mathrm{x}}\right)$ in our lab using thermal evaporation. Therefore, these simulations were able to provide a trend for obtaining high efficiency and eased the process for optimizing various layer thicknesses and other technical parameters. The schematic diagram of $\mathrm{SHJ} \mathrm{LiF}_{x} / \mu c-\mathrm{SiO}(\mathrm{n}) / \mathrm{i}-\mathrm{a}-\mathrm{Si}: \mathrm{H} / \mathrm{n}-\mathrm{c}-\mathrm{Si} / \mathrm{i}-\mathrm{a}-\mathrm{Si}: \mathrm{H} / \mu \mathrm{c}-\mathrm{SiO}(\mathrm{p})$ solar cell is depicted in Figure 1. The basis parameters, thickness variation, and the work function variation for the $\mathrm{SHJ}$ $\mathrm{LiF}_{\mathrm{x}} / \mu \mathrm{c}-\mathrm{SiO}(\mathrm{n}) / \mathrm{i}-\mathrm{a}-\mathrm{Si}: \mathrm{H} / \mathrm{n}-\mathrm{c}-\mathrm{Si} / \mathrm{i}-\mathrm{a}-\mathrm{Si}: \mathrm{H} / \mu \mathrm{c}-\mathrm{SiO}(\mathrm{p})$ solar cell are listed in Table 1 . The work function of transparent conductive oxide (TCO) was fixed as $5.2 \mathrm{eV}$. The $\mathrm{LiF}_{\mathrm{x}}$ film was selected as the electron selective layer, and the particular parameters were optimized in order to accomplish the highest efficiency of the $\mathrm{LiF}_{x} / \mathrm{c}-\mathrm{Si} \mathrm{SHJ}$ solar cell. The influence of the $\mathrm{LiF}_{\mathrm{x}} / \mu \mathrm{c}-\mathrm{SiO}(\mathrm{n})$ interface was studied using an air mass 1.5 (AM 1.5) illumination utilizing AFORS-HET simulated software. Taking advantage of the simulation study, we optimized the solar cell parameters such as the band gap (Eg), work function, and thickness of the $\mathrm{LiF}_{\mathrm{x}}$ layer. Particularly, $\mathrm{LiF}_{\mathrm{x}}$ films have been picked as electron selective contact layers to accomplish the maximum performance of $\mathrm{LiF}_{\mathrm{x}}$-based $\mathrm{SHJ}$ solar cells. Table 1 depicts various simulated parameters employed for the SHJ solar cell structure.

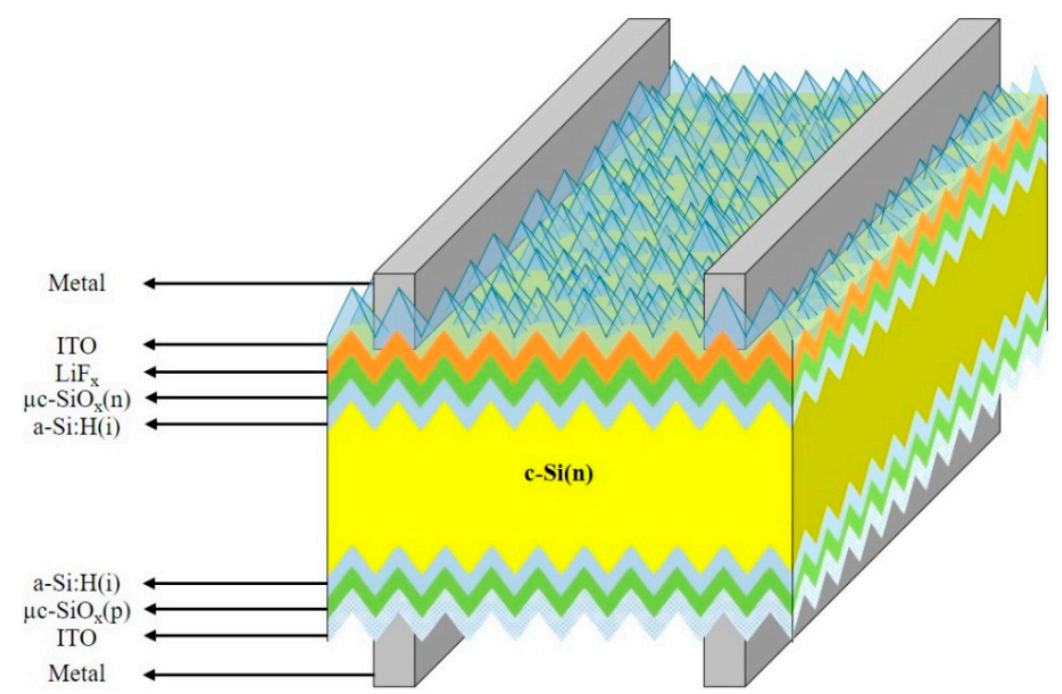

Figure 1. Schematic diagram of the silicon heterojunction $\mathrm{SH}(\mathrm{SHJ})$ solar cell with lithium fluoride $\left(\mathrm{LiF}_{\mathrm{x}}\right)$ as an electron selective carrier layer. 
Table 1. Simulation parameters for $\mathrm{LiF}_{\mathrm{x}}$ and various silicon layers in an electron-based carrier selective contact (CSC) solar cell.

\begin{tabular}{ccccc}
\hline Parameters & a-Si:H (i) & c-Si (n) & LiFx & uc-SiOx (n) \\
\hline Layer thickness (nm) & 3 & 150,000 & 2 & 3 \\
Dielectric constant & 11.9 & 11.9 & 11.9 & 11.9 \\
Electron affinity (eV) & 3.9 & 4.05 & $3.2-3.9$ & 3.9 \\
Band gap (eV) & 1.5 & 1.12 & 11 & 1.9 \\
Optical band gap (eV) & 1.5 & 1.12 & 11 & 1.9 \\
Effective conduction band density $\left(\mathrm{cm}^{-3}\right)$ & $1 \times 10^{20}$ & $2.84 \times 10^{19}$ & $1 \times 10^{20}$ & $1 \times 10^{19}$ \\
Effective valence band density $\left(\mathrm{cm}^{-3}\right)$ & $1 \times 10^{20}$ & $2.68 \times 10^{19}$ & $1 \times 10^{20}$ & $1 \times 10^{19}$ \\
Electron mobility $\left(\mathrm{cm}^{2} \mathrm{~V}^{-1} \mathrm{~s}^{-1}\right)$ & 5 & 1111 & 1 & 50 \\
Hole mobility $\left(\mathrm{cm}^{2} \mathrm{~V}^{-1} \mathrm{~s}^{-1}\right)$ & 1 & 421.6 & 1 & 5 \\
Doping concentration of acceptors $\left(\mathrm{cm}^{-3}\right)$ & 0 & 0 & 0 & 0 \\
Doping concentration of donators $\left(\mathrm{cm}^{-3}\right)$ & 0 & $5 \times 10^{16}$ & $1 \times 10^{7}$ & $1 \times 10^{20}$ \\
Thermal velocity of electrons $\left(\mathrm{cms}^{-1}\right)$ & $1 \times 10^{7}$ & $1 \times 10^{7}$ & $1 \times 10^{7}$ & $1 \times 10^{7}$ \\
Thermal velocity of holes $\left(\mathrm{cms}^{-1}\right)$ & $1 \times 10^{7}$ & $1 \times 10^{7}$ & $1 \times 10^{7}$ & $1 \times 10^{7}$ \\
Layer density (gcm $\left.{ }^{-3}\right)$ & 2.328 & 2.328 & 2.328 & 2.328 \\
\hline
\end{tabular}

The extensive electrical parameters of crystalline as well as amorphous silicon layers mostly stood as per default values in the simulation. The Shockley-Read-Hall recombination model was applied to determine the semiconductor equation for the steady-state condition. Thermionic emission was designed for the carriers crossing through the a-Si:H/c-Si interface. Tunneling was not incorporated, since an improbable tunneling current can influence solar cell performance within regular working conditions [36,37]. We appropriately selected a textured pyramid c-Si substrate structure at the front surface for optical parameters and in the TCO films, keeping in consideration the light absorption and reflection. Nevertheless, as the model furthered, optical effects, such as grid shading, were not considered. The band gap thickness and work function of $\mathrm{LiF}_{\mathrm{x}}$ were varied. Finally, after the optimization of the $\mathrm{LiF}_{\mathrm{x}}$ 's layer parameters, the improved efficiency of $\mathrm{LiF}_{\mathrm{x}}$-based $\mathrm{SHJ}$ solar cell was achieved.

\section{Results and Discussion}

\subsection{Effect of Incorporating a LiF Electron Selective Layer}

Solar cells with $\mathrm{LiF}_{\mathrm{x}}$ as an interfacial layer on the front side and the wider band gap of the $\mathrm{LiF}_{\mathrm{x}}$ layer created a valence band offset in the SHJ solar cell on the top. The example of an inversion layer in the crystalline silicon absorber next to the $\mu \mathrm{c}-\mathrm{SiO}$ was a learning hallmark of this structure, assisting through a prominent barrier towards an electron ensuing from the band bending. For instance, among the $\mathrm{LiF}_{\mathrm{x}}$ /silicon solar cell, trap-assisted tunneling or band-to-band tunneling was a predominant electron transport scheme in favor of the carrier selective contact. Furthermore, in the solar cells, the electrons reached the front surface, needed to pass by a particular potential barrier, induced by the valance band shift among $\mathrm{LiF}_{\mathrm{x}}$ and c-Si, in order for the proceeding movement towards the $\mathrm{LiF}_{\mathrm{x}}$ into the degenerately doped ITO front electrode and the extrication by the silver electrode.

Consequently, it is critical to understand the properties and physical aspects of silicon heterojunction solar cells. Our group studied the consequences of adding an interfacial layer of $\mathrm{LiF}_{\mathrm{x}}$ as an electron carrier selective layer on the functioning of an $\mathrm{SHJ}$ solar cell. Figure 2 shows the influence of $\mathrm{LiF}_{\mathrm{x}}$ thickness on the performance of $\mathrm{SHJ}$ cells. The thickness of the interfacial layer varied from 2 to $40 \mathrm{~nm}$ while keeping the $3 \mathrm{~nm}$ thickness of the intrinsic layer. Figure 2a depicts the current density-voltage $(\mathrm{J}-\mathrm{V})$ characteristics of $\mathrm{SHJ}$ solar cells as a function of $\mathrm{LiF}_{\mathrm{x}}$ thickness. The $\mathrm{J}-\mathrm{V}$ curve shape describes the fill factor (FF) and gives the peak fill factor at $2 \mathrm{~nm}$. As the thickness continued to increase, the FF significantly decreased, while the short-circuit current density began to decline, leading to the great decay of the cells' performance. In a nutshell, for the purpose of gaining improved conversion efficiency of $\mathrm{LiF}_{\mathrm{x}} / \mathrm{c}-\mathrm{Si} \mathrm{SHJ}$ solar cells, the thickness should be controlled properly within a 
particular range. As the thickness of the emitter layer increased, the following were noticed: (i) JSC initially increased, achieving the maximum $\mathrm{J}_{\mathrm{SC}}$ of $38.43 \mathrm{~mA} / \mathrm{cm}^{2}$ for the $\mathrm{LiF}_{\mathrm{x}}$ layer thickness at $2 \mathrm{~nm}$ and then falling linearly. (ii) The value of $\mathrm{V}_{\mathrm{OC}}$ increased primary; as the higher $\mathrm{V}_{\mathrm{OC}}$ value of $746.4 \mathrm{mV}$ was attained at $2 \mathrm{~nm}$, it started to deteriorate. (iii) For the thickness of $2 \mathrm{~nm} \mathrm{LiF}_{\mathrm{x}}$, the efficiency was enhanced initially and then continued to decline fall, reaching the highest value of $23.74 \%$. Therefore, $2 \mathrm{~nm} \mathrm{LiF} \mathrm{x}_{\mathrm{X}}$ will be an optimum layer thickness for future research.

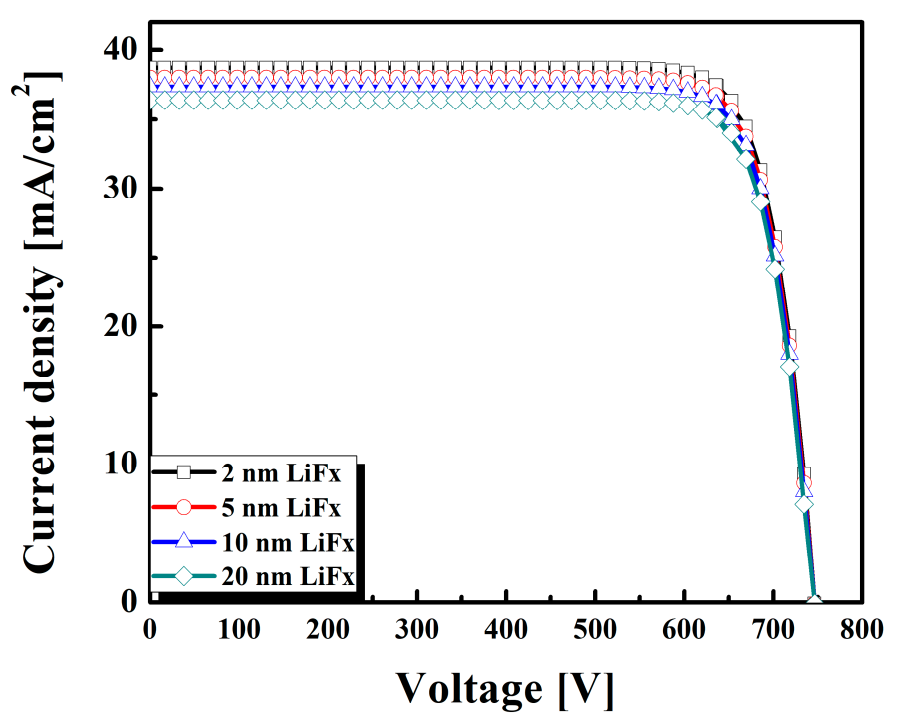

(a)

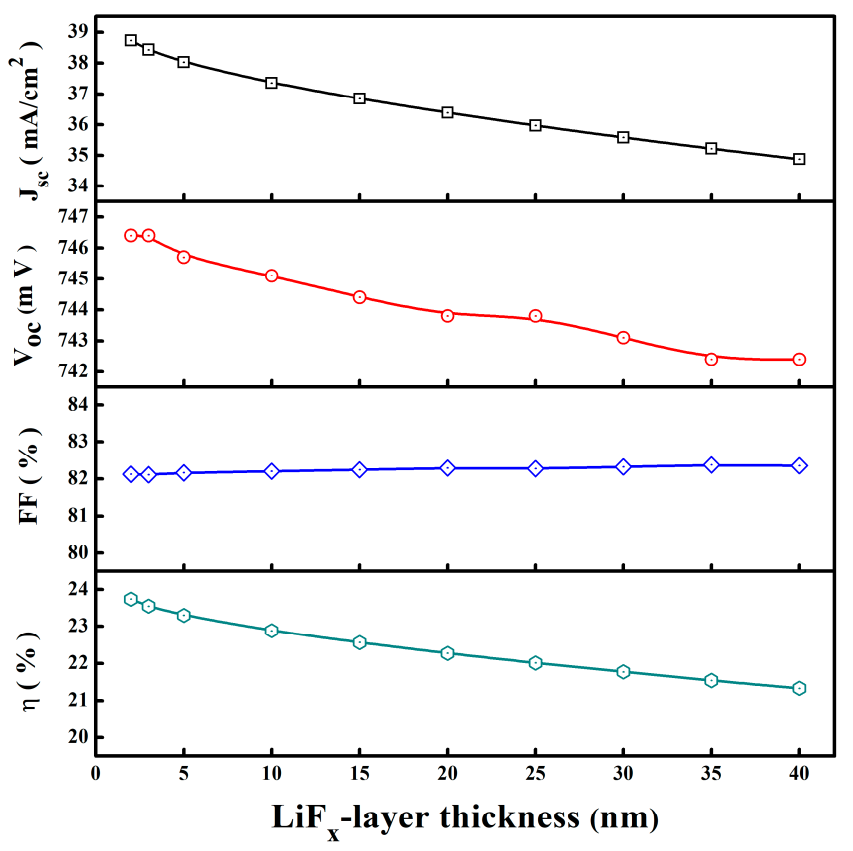

(b)

Figure 2. XXXXXX: The (a) current density-voltage $(\mathrm{J}-\mathrm{V})$ characteristic and (b) performance of the SHJ solar cells as a function of LiFx thickness as an electron selective layer for SHJ solar cells.

Figure $2 \mathrm{~b}$ shows the performance of the $\mathrm{SHJ}$ solar cells for various thicknesses of $\mathrm{LiF}_{\mathrm{x}}$ as an electron selective layer. It was found that the cell parameters, such as the fill factor (FF) and Voc, were 
improved by introducing the LiF interfacial layer, while the solar cell without the LiF layer exhibited the lowest performance. The highest fill factor (FF) was recorded for the $\mathrm{LiF}_{\mathrm{x}}$ thickness of $2 \mathrm{~nm}$. With the further increase of the $\mathrm{LiF}_{\mathrm{x}}$ thickness, the FF remained in contact or increased slowly. The $\mathrm{J}_{\mathrm{sc}}$ was decreased with the increase of $\mathrm{LiF}_{x}$ thickness from 2 to $40 \mathrm{~nm}$, respectively. In a nutshell, to acquire an ameliorated performance of $\mathrm{SHJ}$ solar cells, the optimized thickness was considered as an important parameter. While the $\mathrm{LiF}_{\mathrm{x}}$ thickness of $2 \mathrm{~nm}$ was employed, the conversion efficiency reached up to $23.74 \%$, and $\mathrm{V}_{\mathrm{oc}}$ improved up to $746.4 \mathrm{mV}$. Above a $2 \mathrm{~nm}$ thickness, entire cell parameters were degraded. The reduced thickness was conducive toward the built-in electric field in favor of increased carrier transport and conveyed the field passivation effect to successfully distinguish the carriers to the prevent particular interface defect capture effect.

Figure 3 shows the external quantum efficiency (EQE) of $\mathrm{SHJ}$ solar cells for $\mathrm{LiF}_{\mathrm{x}}$ as an electron carrier selective contact layer. The figure shows that at about a $2 \mathrm{~nm} \mathrm{LiF}_{x}$ thickness, the QE of the devices indicate the highest spectral response for long wavelength regions. As renowned, such $\mathrm{LiFs}$ had a high dipole moment in a molecular scale and the ITO work function was diminished, since $\mathrm{LiF}_{\mathrm{x}}$ was coupled to ITO. The mitigation of the work function because of the LiF being coupled to the ITO triggered the lower barrier height in favor of the electron injection in HIT solar cells; consequently, there was a lower amount of carrier collection around the interface and, at the same time, a lowered surface recombination velocity as well as a consequently improved spectral response for long wavelengths [17]. A substantial increase is visible as well as in the blue region. The band gap of the $\mathrm{LiF}_{\mathrm{x}}$ electron selective carrier layer $(3.9 \mathrm{eV})$ was much wider, ensuring a low light absorption or optical losses on the front side of the solar cell. These consequences forecast various optical and electrical advantages of $\mathrm{LiF}_{\mathrm{x}}$ as a carrier selective contact layer for various optoelectronic properties and band gap alignment.

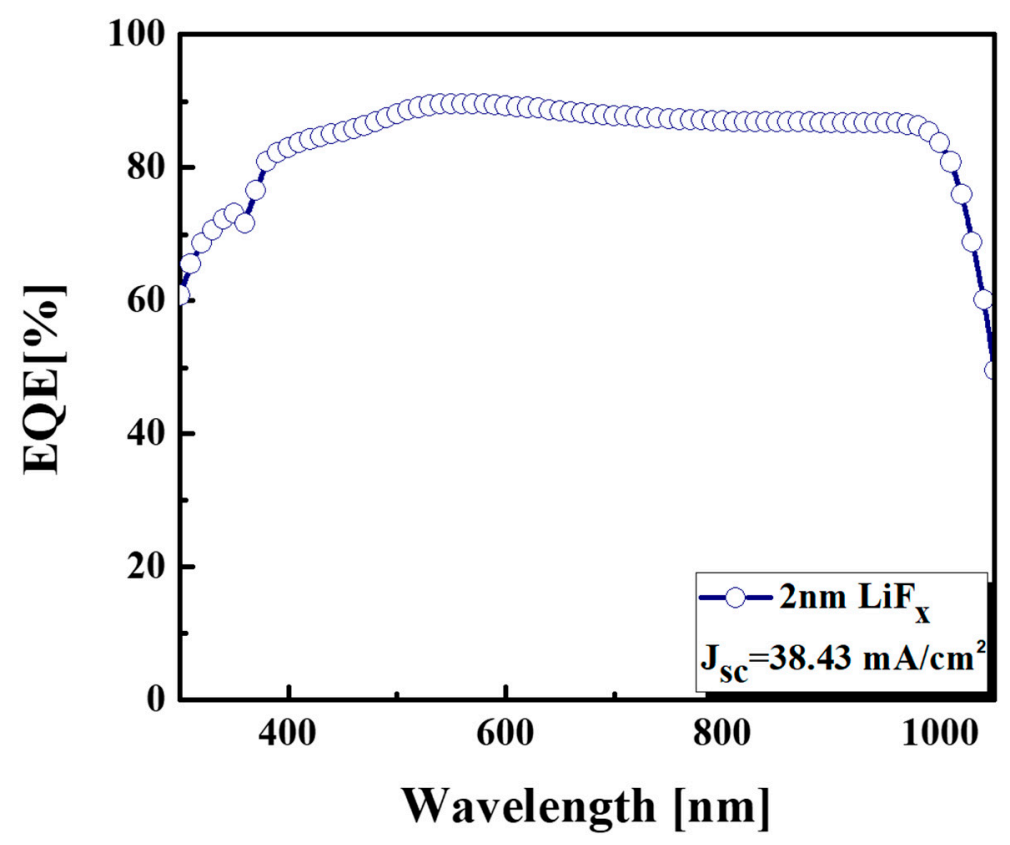

Figure 3. External quantum efficiency (EQE) of $\mathrm{SHJ}$ solar cells for a $2 \mathrm{~nm}$ thick $\mathrm{LiF}_{\mathrm{x}}$ as an electron carrier selective contact layer.

\subsection{Surface Effect Passivation}

Figure 4 depicts the electric field of $\mathrm{SHJ}$ solar cells for $\mathrm{LiF}_{\mathrm{x}}$ as an electron carrier selective contact layer. Due to the large energy barrier, a slight potential drop was noticed on the c-Si substrate compared with SHJ solar cells. Although in valence band the hetero-structured energy band shift leads to holes collection on the interface of the heterojunction, a significant reduction in electron density results in a particular surface-effect passivation. Hence, the conversion efficiency of the $\mathrm{LiF}_{\mathrm{x}} / \mathrm{c}-\mathrm{Si}$ silicon heterojunction solar cell was more than that of particular SHJ solar cells at an imparted thickness. 
In addition, the surface effect passivation ameliorated the silicon heterojunction solar cells' performance. It is renowned that Energy bands that bend at the silicon surface by the generation of an electric field can provide an energy barrier for charge accumulation at the interface, and the recombination rate is greatly reduced, as the electron/hole concentration are imbalanced-a mechanism called the field effect passivation.

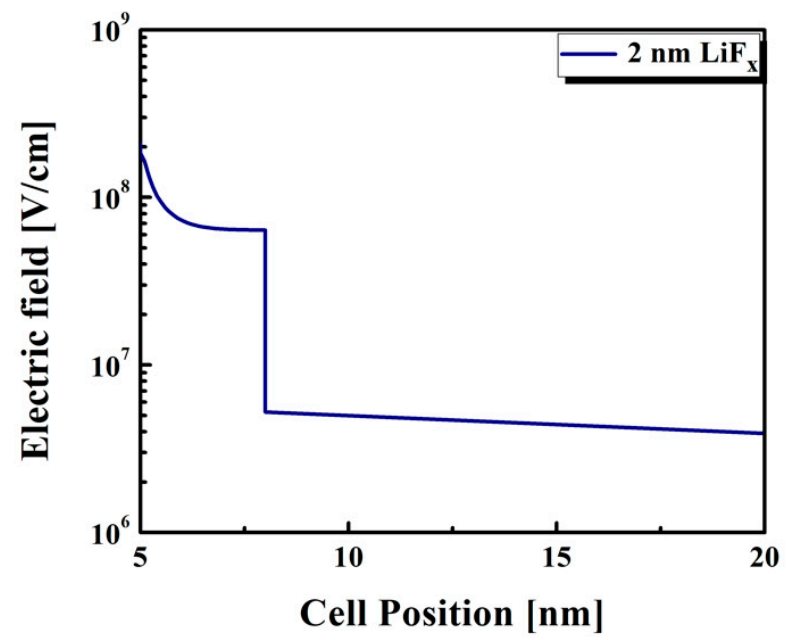

Figure 4. Electron field of $\mathrm{SHJ}$ solar cell for a $2 \mathrm{~nm}$ thick $\mathrm{LiF}_{\mathrm{x}}$ as an electron carrier selective contact layer.

\subsection{Effect of Work Function in a LiF Electron Selective Layer}

For the further realization of the impact of work function upon the SHJ solar cells, we implemented a relative analysis of the band diagram regarding a different work function. The band diagram of SHJ solar cells for various work functions of the $\mathrm{LiF}_{\mathrm{x}}$ layer using a standard AM 1.5 is shown in Figure 5 . The clear changes in the energy band were noticed with the variation of $\mathrm{LiF}_{\mathrm{x}}$ work function. As the work function value was low, the band bending occurs in the conduction band of $\mathrm{LiF}_{\mathrm{x}}$. Therefore, it is easy to collect the electrons and improve the fill factor and efficiency by reducing the recombination at the $\mathrm{LiFx} / \mu \mathrm{c}-\mathrm{SiO}$ interface. With the increase of $\mathrm{LiF}_{\mathrm{x}}$ work function, the following points were observed: (i) Schottky barrier height increased, (ii) degradation in $\mathrm{J}_{\mathrm{sc}}, \mathrm{V}_{\mathrm{oc}}$, and $\eta$ was noticed. The depletion region almost vanished in the $\mathrm{c}-\mathrm{Si}$ side at a $3.9 \mathrm{eV}$ work function after the decay of the conduction band barrier height $\left(\mathrm{V}_{\mathrm{D}}\right)$ among the $\mathrm{n}-\mathrm{c}-\mathrm{Si}$ layer and LiFx layer, leading towards the collection of the electron at $\mathrm{LiF}_{\mathrm{x}} / \mathrm{c}-\mathrm{Si}$ interface. The $\mathrm{V}_{\mathrm{D}}$ portrays the barrier height of holes transfer from $\mathrm{n}-\mathrm{c}-\mathrm{Si}$ to $\mathrm{LiF}$ in the conduction band that assists us to realize the amendments in the built-in field.

The J-V behavior of a $\mathrm{LiF}_{\mathrm{x}} / \mu \mathrm{c}-\mathrm{SiO}(\mathrm{n})$ electron carrier selective cell is presented in Figure $6 \mathrm{a}$, denoting an efficiency of $23.74 \%$ was achieved up to the proof-of-concept level of this technology. The short circuit current $\mathrm{J}_{\mathrm{sc}}$ and open circuit voltage $\mathrm{V}_{\mathrm{oc}}$ was evaluated to be $38.73 \mathrm{~mA} \mathrm{~cm}-2$ and $746 \mathrm{mV}$, respectively, illustrating that the recombination as well as optical benefits of confining the front contact to a smaller area were understood. Furthermore, we accomplished a fill factor of $82.12 \%$ at $3.9 \mathrm{eV}$ work function of $\mathrm{LiF}_{\mathrm{x}}$ film. The $\mathrm{J}-\mathrm{V}$ curve shape describes the fill factor $(\mathrm{FF})$, and it gives the peak fill factor at $3.9 \mathrm{eV}$. As the work function increased, the barrier height was affected. As the work function increased, the efficiency of our cell started to decrease. 


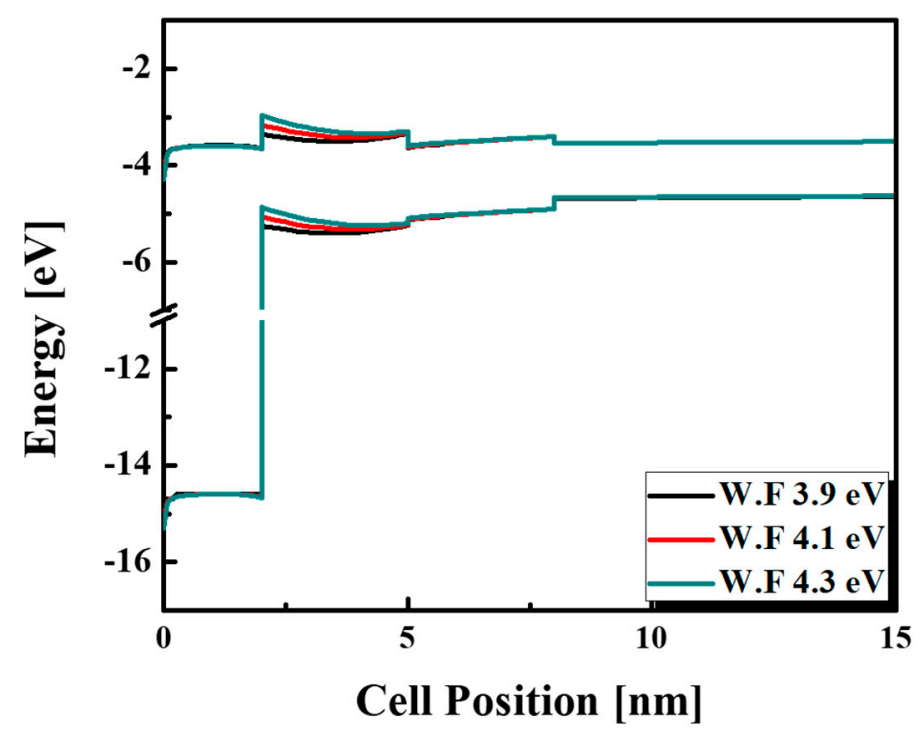

Figure 5. Band diagram of SHJ solar cells for various work functions of the $\mathrm{LiF}_{\mathrm{x}}$ layer.

In the conduction band, electrons were moving from n-c-Si to $\mathrm{LiF}_{\mathrm{x}}$ layer with barrier height, which assisted us to realize the particular variation in the built-in field. The diminishing of the barrier height was associated with the declination of a built-in field that directly led to an abrupt diminution of the open circuit voltage. We also scrutinized the influence of the barrier height upon the short-circuit current, because of the unfavorable barrier added with the lowered barrier height to obstruct the accumulation of electron flow through the n-type crystalline silicon towards the front contact. This collected a prominent number of electrons, which may problematic when extracted, and lead to an abrupt decrease of the JSC.

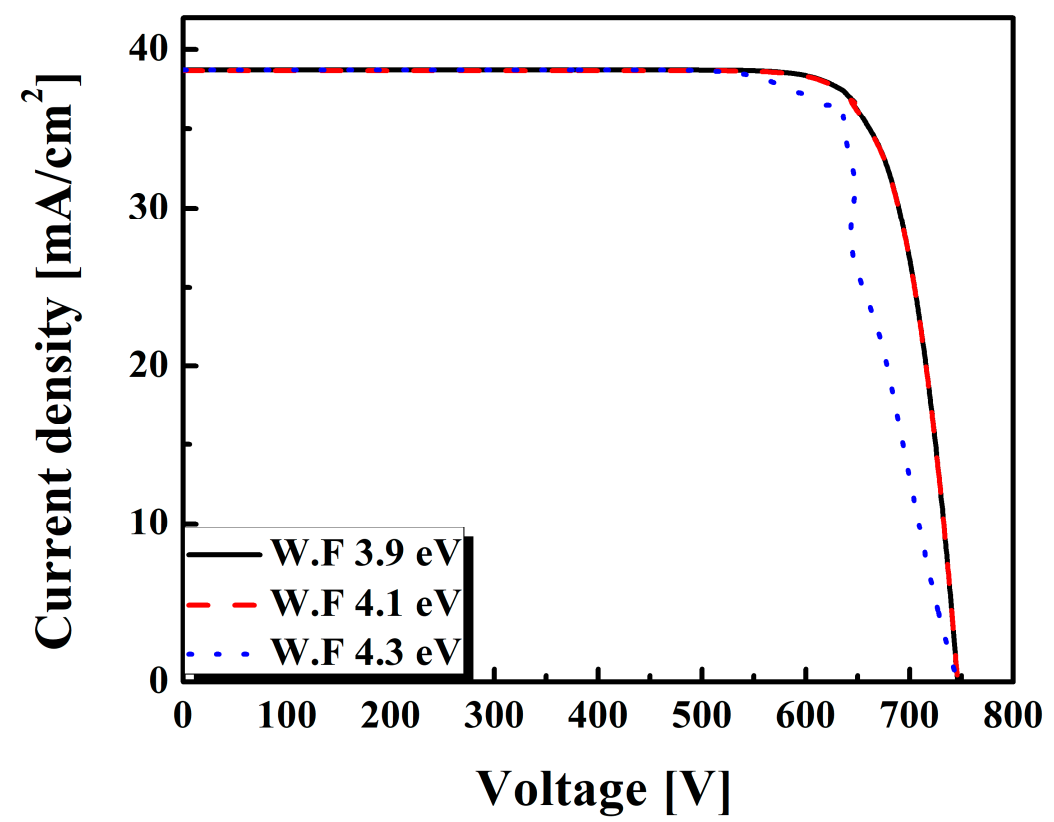

(a)

Figure 6. Cont. 


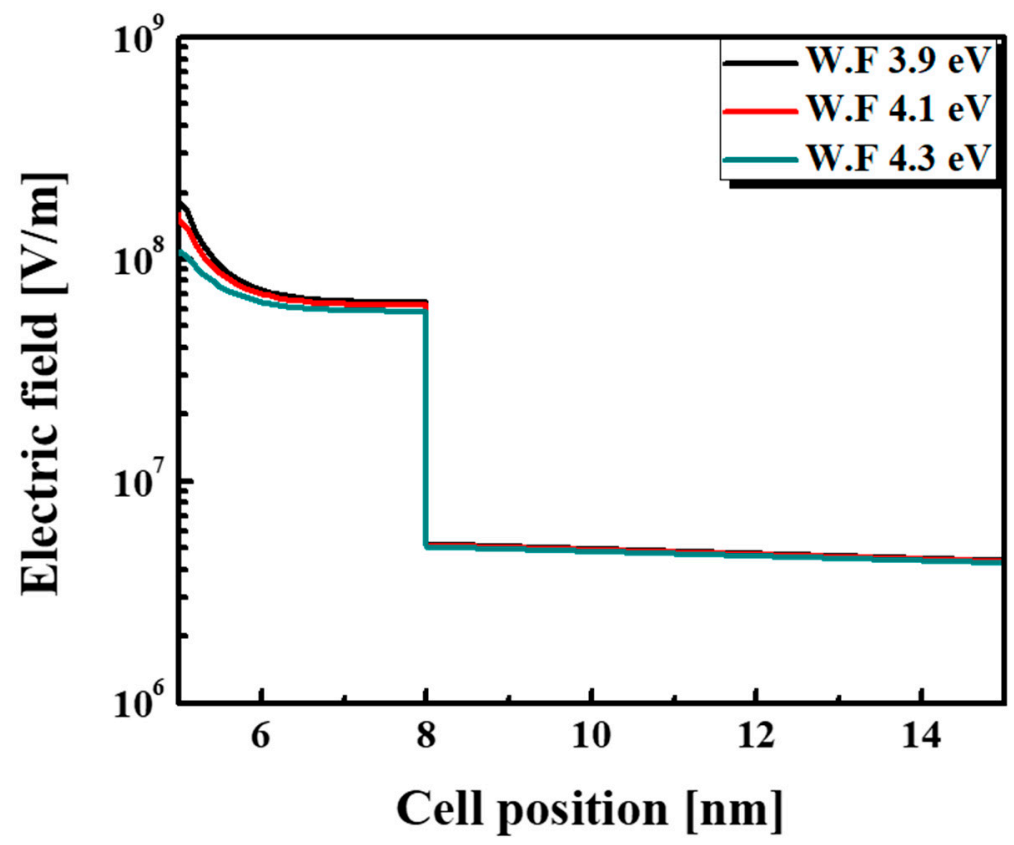

(b)

Figure 6. The (a) current density-voltage (J-V) and (b) electric field of the SHJ solar cells for various work functions of the $\mathrm{LiF}_{\mathrm{x}}$ as an electron selective layer.

As a result, a faster alteration in the energy band occurred because the concentration of the defect state was greater adjacent to a particular c-Si wafer as shown in Figure 6b. It is known that "energy bands that bend at the silicon surface by the generation of an electric field can provide an energy barrier for charge accumulation at the interface, and the recombination rate is greatly reduced as the electron/hole concentration are imbalance", [38] and that mechanism is called the field effect passivation. Since $\mathrm{LiF}_{\mathrm{x}} / \mathrm{c}-\mathrm{Si}$ silicon heterojunction solar cells gradually increased the electric field of the heterojunction with the reduction of the work function from 4.3 to 3.9, the ameliorated surface effect passivation at the interface of the heterojunction the electrons were moderately repelled.

\section{Conclusions}

In summary, we conducted a simulation of the influence of various parameters, such as thickness, work function, and the electric field, of $\mathrm{LiF}_{\mathrm{x}}$ as a carrier selective contact layer for $\mathrm{SHJ}$ $\left(\mathrm{LiF}_{\mathrm{x}} / \mathrm{n}-\mu \mathrm{c}-\mathrm{SiO} \mathrm{x} / \mathrm{i}-\mathrm{a}-\mathrm{Si} / \mathrm{n}-\mathrm{c}-\mathrm{Si}\right)$ solar cells. We found that by adding a very thin $\mathrm{LiF}_{\mathrm{x}}$ layer, particularly $\mathrm{V}_{\mathrm{OC}}$, the $\mathrm{SHJ}$ solar cell was elevated, leading to better conversion efficiency. The $\mathrm{LiF}_{\mathrm{x}}$ layer, by means of its wider band gap and higher electron affinity, developed a prominent conduction band offset at the front side to repel particular electron diffusions. Furthermore, the higher transmittance and lower resistivity of the $\mathrm{LiF}_{\mathrm{x}}$ film degraded the series resistance and ameliorated the long and short wavelength responses of solar cells. While using an optimized $2 \mathrm{~nm}$ thickness of $\mathrm{LiF}_{\mathrm{x}}$, a conversion efficiency of $23.74 \%$ was achieved with $\mathrm{J}_{\mathrm{sc}} 38.73 \mathrm{~mA} / \mathrm{cm}^{2}$ and $\mathrm{V}_{\mathrm{oc}} 746.4 \mathrm{mV}$. Moreover, we illustrated the surface effect of passivation in the solar cells by presenting particular amendments into an electric field and band offset. Thus, the SHJ solar cell has a much better surface passivation execution, and a superior $\mathrm{V}_{\mathrm{OC}}$ can be received to assure maximum conversion efficiency. We believe the $\mathrm{LiF}_{\mathrm{x}} / \mathrm{c}-\mathrm{Si}$ heterojunction strategy proposed herein has novel possibilities towards highly efficient $\mathrm{SHJ}$ solar cells.

Author Contributions: Conceptualization, M.Q.K.; formal analysis, S.L. and D.P.P.; writing一original draft preparation, M.Q.K.; writing—review and editing, S.Q.H., H.P. and E.-C.C.; visualization, Y.K.; supervision, E.-C.C. and J.Y. All authors have read and agreed to the published version of the manuscript.

Funding: This work was supported by the Korea Institute of Energy Technology Evaluation and Planning (KETEP) and the Ministry of Trade, Industry and Energy (MOTIE) (No. 20173010012940) and (No. 20183010014270). 
Conflicts of Interest: The authors declare no conflict of interest.

\section{References}

1. Tanaka, M.; Taguchi, M.; Matsuyama, T.; Sawada, T.; Tsuda, S.; Nakano, S.; Hanafusa, H.; Kuwano, Y. Development of new a-Si/c-Si heterojunction solar cells: ACJ-HIT (artificially constructed junction-heterojunction with intrinsic thin-layer). Jpn. J. Appl. Phys. 1992, 31, 3518. [CrossRef]

2. Lozac'h, M.; Nunomura, S.; Sai, H.; Matsubara, K. Passivation property of ultrathin SiOx:H/a-Si:H stack layers for solar cell applications. Sol. Energy Mater. Sol. Cells 2018, 185, 8-15. [CrossRef]

3. Descoeudres, A.; Allebé, C.; Badel, N.; Barraud, L.; Champliaud, J.; Christmann, G.; Debrot, F.; Faes, A.; Geissbühler, J.; Horzel, J.; et al. Low-temperature processes for passivation and metallization of high-efficiency crystalline silicon solar cells. Sol. Energy 2018, 175, 54-59. [CrossRef]

4. Green, M.A.; Emery, K.; Hishikawa, Y.; Warta, W.; Dunlop, E.D. Solar cell efficiency tables (Version 45). Prog. Photovolt. Res. Appl. 2015, 23, 1-9. [CrossRef]

5. Liu, J.; Yao, Y.; Xiao, S.; Gu, X. Review of status developments of high-efficiency crystalline silicon solar cells. J. Phys. D 2018, 51, 123001. [CrossRef]

6. Taguchi, M.; Yano, A.; Tohoda, S.; Matsuyama, K.; Nakamura, Y.; Nishiwaki, T.; Fujita, K.; Maruyama, E. 24.7\% record efficiency HIT solar cell on thin silicon wafer. IEEE J. Photovolt. 2013, 4, 96-99. [CrossRef]

7. Mazzarella, L.; Morales-Vilches, A.B.; Korte, L.; Schlatmann, R.; Stannowski, B. Ultra-thin nanocrystalline n-type silicon oxidefront contact layers for rear-emitter silicon heterojunction solar cells. Sol. Energy Mater. Sol. Cells 2018, 179, 386-391. [CrossRef]

8. Masuko, K.; Shigematsu, M.; Hashiguchi, T.; Fujishima, D.; Kai, M.; Yoshimura, N.; Yamaguchi, T.; Ichihashi, Y.; Mishima, T.; Matsubara, N.; et al. Achievement of more than 25\% conversion efficiency with crystalline silicon heterojunction solar cell. IEEE J. Photovolt. 2014, 4, 1433-1435. [CrossRef]

9. De Wolf, S.; Descoeudres, A.; Holman, Z.C.; Ballif, C. High-efficiency silicon heterojunction solar cells: A Review. Green 2012, 2, 7-24. [CrossRef]

10. Alibakhshikenari, M.; Virdee, B.S.; See, C.H.; Abd-Alhameed, R.A.; Falcone, F.; Limit, E. High-Performance $50 \mu \mathrm{m}$ Silicon-Based On-Chip Antenna with High Port-to-Port Isolation Implemented by Metamaterial and SIW Concepts for THz Integrated Systems. In Proceedings of the 13th International Congress on Artificial Materials for Novel Wave Phenomena-Metamaterials 2019, Rome, Italy, 16-21 September 2019.

11. Shamim, A.; Salama, K.N.; Soliman, E.A.; Sedky, S. On-chip antenna: Practical design and characterization considerations. In Proceedings of the 14th International Symposium on Antenna Technology and Applied Electromagnetics \& the American Electromagnetics Conference, Ottawa, ON, Canada, 5-8 July 2010.

12. Alibakhshikenari, M.; Virdee, B.S.; See, C.H.; Abd-Alhameed, R.A.; Falcone, F.; Limiti, E. Silicon-Based 0.450-0.475 THz Series-Fed Double Dielectric Resonator On-Chip Antenna Array Based on Metamaterial Properties for Integrated-Circuits. In Proceedings of the 13th International Congress on Artificial Materials for Novel Wave Phenomena-Metamaterials 2019, Rome, Italy, 16-21 September 2019.

13. Deckmyn, T.; Agneessens, S.; Reniers, A.C.; Smolders, A.B.; Cauwe, M.; Ginste, D.V.; Rogier, H. A novel $60 \mathrm{GHz}$ wideband coupled half-mode/quarter-mode substrate integrated waveguide antenna. IEEE Trans. Antennas Propag. 2017, 65, 6915-6926. [CrossRef]

14. Alibakhshikenari, M.; Virdee, B.S.; See, C.H.; Abd-Alhameed, R.A.; Falcone, F.; Limiti, E. Overcome the Limitations of Performance Parameters of On-Chip Antennas Based on Metasurface and Coupled Feeding Approaches for Applications in System-on-Chip for THz Integrated-Circuits. In Proceedings of the Asia-Pacific Microwave Conference (APMC), Marina Bay Sands, Singapore, 10-13 December 2019.

15. Sam, S.; Lim, S. Electrically small complementary split-ring resonator antenna on eighth-mode substrate integrated waveguide. Electron. Lett. 2013, 49, 519-521. [CrossRef]

16. Alibakhshikenari, M.; Virdee, B.S.; See, C.H.; Abd-Alhameed, R.; Falcone, F.; Limiti, E. A Novel 0.3-0.31 THz GaAs-Based Transceiver with On-Chip Slotted Metamaterial Antenna Based on SIW Technology. In Proceedings of the Asia-Pacific Microwave Conference (APMC), Marina Bay Sands, Singapore, 10-13 December 2019. in press. 
17. Alibakhshikenari, M.; Virdee, B.S.; See, C.H.; Abd-Alhameed, R.A.; Limiti, E. High Performance On-Chip Array Antenna Based on Metasurface Feeding Structure for Terahertz Integrated Circuits. In Proceedings of the 44th International Conference on Infrared, Millimeter, and Terahertz Waves (IRMMW-THz), Paris, France, 1-6 September 2019.

18. Battaglia, C.; Cuevas, A.; de Wolf, S. High-efficiency crystalline silicon solar cells: Status and perspectives. Energy Environ. Sci. 2016, 9, 1552-1576. [CrossRef]

19. De Wolf, S.; Kondo, M. Nature of doped a-Si: H/c-Si interface recombination. J. Appl. Phys. 2009, 105, 103707. [CrossRef]

20. Hussain, S.Q.; Mallem, K.; Kim, Y.J.; Le, A.H.T.; Khokhar, M.Q.; Kim, S.; Dutta, S.; Sanyal, S.; Kim, Y.; Park, J. Ambient annealing influence on surface passivation and stoichiometric analysis of molybdenum oxide layer for carrier selective contact solar cells. Mater. Sci. Semicond. Process. 2019, 91, 267-274. [CrossRef]

21. Mallem, K.; Kim, Y.J.; Hussain, S.Q.; Dutta, S.; Le, A.H.T.; Ju, M.; Park, J.; Cho, Y.H.; Kim, Y.; Cho, E.-C. Molybdenum oxide: A superior hole extraction layer for replacing p-type hydrogenated amorphous silicon with high efficiency heterojunction Si solar cells. Mater. Res. Bull. 2019, 110, 90-96. [CrossRef]

22. Bivour, M.; Messmer, C.; Neusel, L.; Zähringer, F.; Schön, J.; Glunz, S.; Hermle, M. Principles of carrier-selective contacts based on induced junctions. In Proceedings of the 33rd European PV Solar Energy Conference and Exhibition, Amsterdam, The Netherlands, 25-29 September 2017; pp. 25-29.

23. Bivour, M.; Temmler, J.; Zähringer, F.; Glunz, S.; Hermle, M. High work function metal oxides for the hole contact of silicon solar cells. In Proceedings of the 2016 IEEE 43rd Photovoltaic Specialists Conference (PVSC), Portland, OR, USA, 5-10 June 2016; pp. 0215-0220. [CrossRef]

24. Xu, X.; Liu, Z.; Zuo, Z.; Zhang, M.; Zhao, Z.; Shen, Y.; Zhou, H.; Chen, Q.; Yang, Y.; Wang, M. Hole selective $\mathrm{NiO}$ contact for efficient perovskite solar cells with carbon electrode. Nano Lett. 2015, 15, 2402-2408. [CrossRef]

25. Ali, Z.; Shakir, I.; Kang, D.J. Highly efficient photoelectrochemical response by sea-urchin shaped ZnO/TiO 2 nano/micro hybrid heterostructures co-sensitized with CdS/CdSe. J. Mater. Chem. A 2014, 2, 6474-6479. [CrossRef]

26. Cho, J.; Melskens, J.; Debucquoy, M.; Payo, M.R.; Jambaldinni, S.; Bearda, T.; Gordon, I.; Szlufcik, J.; Kessels, W.; Poortmans, J. Passivating electron-selective contacts for silicon solar cells based on an a-Si: $\mathrm{H} / \mathrm{TiO}_{\mathrm{x}}$ stack and a low work function metal. Prog. Photovolt. Res. Appl. 2018, 26, 835-845. [CrossRef]

27. Bullock, J.; Zheng, P.; Jeangros, Q.; Tosun, M.; Hettick, M.; Sutter-Fella, C.M.; Wan, Y.; Allen, T.; Yan, D.; Macdonald, D. Lithium Fluoride Based Electron Contacts for High Efficiency n-Type Crystalline Silicon Solar Cells. Adv. Energy Mater. 2016, 6, 1600241. [CrossRef]

28. Wan, Y.; Samundsett, C.; Bullock, J.; Allen, T.; Hettick, M.; Yan, D.; Zheng, P.; Zhang, X.; Cui, J.; McKeon, J. Magnesium fluoride electron-selective contacts for crystalline silicon solar cells. ACS Appl. Mater. Interfaces 2016, 8, 14671-14677. [CrossRef]

29. Ye, F.; Yang, W.; Luo, D.; Zhu, R.; Gong, Q. Applications of cesium in the perovskite solar cells. J. Semicond. 2017, 38, 011003. [CrossRef]

30. Upama, M.B.; Elumalai, N.K.; Mahmud, M.A.; Wright, M.; Wang, D.; Xu, C.; Haque, F.; Chan, K.H.; Uddin, A. Interfacial engineering of electron transport layer using Caesium Iodide for efficient and stable organic solar cells. Appl. Surf. Sci. 2017, 416, 834-844. [CrossRef]

31. Fallahazad, P.; Naderi, N.; Eshraghi, M.J.; Massoudi, A. Combination of surface texturing and nanostructure coating for reduction of light reflection in $\mathrm{ZnO} / \mathrm{Si}$ heterojunction thin film solar cell. J. Mater. Sci. Mater. Electron. 2018, 29, 6289-6296. [CrossRef]

32. Yang, X.; Zheng, P.; Bi, Q.; Weber, K. Silicon heterojunction solar cells with electron selective TiO $\mathrm{T}_{\mathrm{x}}$ contact. Sol. Energy Mater. Sol. Cells 2016, 150, 32-38. [CrossRef]

33. Mack, I.; Stuckelberger, J.; Wyss, P.; Nogay, G.; Jeangros, Q.; Horzel, J.; Allebé, C.; Despeisse, M.; Haug, F.J.; Ingenito, A.; et al. Properties of mixed phase silicon-oxide-based passivating contacts for silicon solar cells. Sol. Energy Mater. Sol. Cells 2018, 181, 9-14. [CrossRef]

34. Hussain, S.; Kim, S.; Ahn, S.; Park, H.; Le, A.; Lee, S.; Lee, Y.; Lee, J.; Yi, J. RF magnetron sputtered ITO:Zr thin films for the high efficiency a-Si:H/c-Si heterojunction solar cells. Met. Mater. Int. 2014, 20, 565-569. [CrossRef] 
35. Hussain, S.Q.; Kim, S.; Ahn, S.; Balaji, N.; Lee, Y.; Lee, J.H.; Yi, J. Influence of high work function ITO:Zr films for the barrier height modification in a-Si:H/c-Si heterojunction solar cells. Sol. Energy Mater. Sol. Cells 2014, 122, 130-135. [CrossRef]

36. He, J.; Zhang, W.; Ye, J.; Gao, P. 16\% efficient silicon/organic heterojunction solar cells using narrow band-gap conjugated polyelectrolytes based low resistance electron-selective contacts. Nano Energy 2018, 43, 117-123. [CrossRef]

37. Liu, Y.; Zhang, J.; Wu, H.; Cui, W.; Wang, R.; Ding, K.; Lee, S.; Sun, B. Low-temperature synthesis TiO passivation layer for organic-silicon heterojunction solar cell with a high open-circuit voltage. Nano Energy 2017, 34, 257-263. [CrossRef]

38. De Nicolas, S.M. A-Si: H/c-Si Heterojunction Solar Cells: Back Side Assessment and Improvement. Ph.D. Thesis, Université Paris Sud-Paris XI, Orsay, France, 2012.

(C) 2020 by the authors. Licensee MDPI, Basel, Switzerland. This article is an open access article distributed under the terms and conditions of the Creative Commons Attribution (CC BY) license (http://creativecommons.org/licenses/by/4.0/). 